\title{
Long and short revolutions towards the Neolithic in western Anatolia and Aegean
}

\author{
Barbara Horejs \\ Institute for Oriental and European Archaeology, Austrian Academy of Sciences, Vienna, AT \\ barbara.horejs@oeaw.ac.at
}

\begin{abstract}
This paper provides an overview of our current knowledge about the transformation towards the Neolithic in western Anatolia and the Aegean, and offers a narrative for their interpretation. Within the longue durée perspective of the long revolution in the Near East, the first millennia of the Holocene of the Aegean and western Anatolia are contrasted with each other. Economic strategies, environmental conditions, technologies, raw material procurement and cultural practices in the Aegean Mesolithic and the Pre-Neolithic times in western Anatolia are analysed to classify potential similarities and differences. The evidence of new cultural and symbolic practices, economies, and technologies in the seventh millennium is discussed as the paradox of a short revolution embedded in a long-term process of interaction, knowledge-transfer and adaptation, setting the scene for the Neolithic pioneers establishing a new social life.
\end{abstract}

KEY WORDS - Neolithic pioneers; social life; practices; technologies; western Anatolia

\author{
Dolge in kratke revolucije $k$ neolitiku \\ $v$ zahodni Anatoliji in v Egejskem morju
}

\begin{abstract}
IZVLEČEK - V članku predstavljamo pregled trenutnih podatkov o spremembah, ki so vodile $k$ neolitiku na območju zahodne Anatolije in Egejskega morja, ter ponujamo pripovedi za njihovo interpretacijo. V okviru perspektive dolgoročnih zgodovinskih procesov (fr. longue durée) na Bližnjem Vzhodu, Prvo tisočletje v holocenu je v okviru perspektive dolgoročnih zgodovinskih procesov (fr. longue durée) na Bližnjem Vzhodu potekalo različno na območju Egejskega morja in v zahodni Anatoliji. Za ovrednotenje morebitnih podobnosti in razlik med mezolitikom na območju Egejskega morja in pred-neolitikom na območju zahodne Anatolije smo ovrednotili gospodarske strategije, okoljske pogoje, tehnologije, oskrbo s surovinami in kulturne običaje. V članku nadalje razpravljamo o novih kulturnih in simbolnih običajih, gospodarstvih in tehnologijah v sedmem tisočletju, ki predstavljajo paradoks kratke revolucije, ki je zakoreninjena $v$ dolgoročnih procesih interakcije, prenosa znanj in prilagoditev, kar je omogočilo neolitskim pionirjem vzpostavitev novega družbenega življenja.
\end{abstract}

KLJUČNE BESEDE - neolitski pionirji; družbeno življenje; običaji; tehnologije; zahodna Anatolija

Dedicated to Klaus Schmidt (i)

who inspired Neolithic research far beyond Anatolia

\section{Introduction}

Decades of intensive research, discoveries of new sites and an interdisciplinary approach in late Pleistocene and early Holocene archaeology are strongly linked with Gordon Childe's 'Neolithic Revolution' concept. While the revolutionary aspect of the cru- cial transformation process is doubtlessly evident, fundamentals other than changes in the economy have been integrated into the discussion and opened significant, new horizons (Schmidt 2006). Cognitive and cultural changes have been defined as pivotal 
agents of change as well. Following Trevor Watkins (2005) concept, the "Neolithic Revolution can be understood as the discovery by humans of the potential of material culture for the storage and transmission of ideas and concepts, elements of symbolic reference". This cultural and cognitive approach additionally extended the timeline by pushing the beginning of the revolution further back into the Epipaleolithic, when the transformation of new social life began in south-west Asia $c .23000$ years ago (Watkins 2010; 2018). The societies in the regions of western Anatolia and the Aegean faced these fundamental changes in a different way and later in time, but were related with the long revolution in many ways. The 'farming frontier' between central Anatolia in the $9^{\text {th }}$ millennium $\mathrm{BC}$ and the regions further west reflects the diverse pathways towards the Neolithic, where a lag of $c .2000$ years is evident in the current data sets (Brami, Zanotti 2015; Brami, Horejs in press). The mosaic-like pattern in western Anatolia and the Aegean shows the diverse trajectories in the transformation process of the Neolithisation. There are nevertheless some similarities and differences in the communities' ways of managing cultural and social life, adopting new subsistence strategies, and integrating new technologies, that allow the incorporation of the regions into a broader narrative.

\section{Diversities in Aegean and Anatolian archaeology}

The early Holocene in the Aegean and western Anatolia (modern Greece and western Turkey) is nowadays embedded in a different narrative than the core zones of the Levant and Mesopotamia. Although situated in direct proximity of central Anatolia and the eastern Mediterranean - both parts of the Neolithic core zones - the long-term transformation between 10000 and $6000 \mathrm{BC}$ in these cores is discussed differently and mostly separately. The academic segregation of east from west in discussions of the Neolithisation process, especially in Aegean archaeology, developed in the few last decades for several reasons, including the influence of post-processualist theories and the tendency towards national or regional specialization in archaeology. This decoupling process might additionally lie in the strong influence of Near Eastern and Anatolian archaeology in the early days of the spectacular discoveries of Kathleen M. Kenyon, Robert J. Braidwood, James Mellaart and other pioneers, only very simply summarized here as the concept of 'ex oriente lux' (Kotsakis 2008). Since the first excavations of the oldest Neolithic settlements on the Greek mainland in the 1950s' by Demetrios Theocharis and Vladimir Milojčić (Milojčić 1950; Theocharis 1973), the impact of new information from the Near East on research in Greece has understandably been enormous. Not only the exchange of knowledge on a personal level, but also the terminology and cultural concept of Neolithisation as defined in the Levant were integrated into interpretations of the early Neolithic of the Greek mainland, mainly in Thessaly, and in Knossos on Crete (Kotsakis 2008; Reingruber 2015). While discussions about the evidence and dating of the so-called Preceramic or Aceramic phases in the early Neolithic rooted in these early days are still ongoing, the model of an Aegean Neolithic pathway that is different from the Levant is now widely accepted.

Scholars working in western Anatolia have had different conceptualizations of the long-term process of Neolithisation. The early excavations of James Mellaart in Hacilar in the 1950s (Mellaart 1958; 1970; Brami, Heyd 2011), followed by Refik Duru's investigations in the Lake District (recently: Duru 2012) and Mehmet Özdoğan's early work in the Marmara region and in Turkish Thrace were strongly influenced by the results of research in the rest of Anatolia, and frequently contextualized with the various regions of the huge landmass (e.g., Özdoğan et al. 2012). The additional establishment of a Turkish-international academic community, especially since the 1970s, has also led to an intensification of western Anatolian investigations regarding prehistory, again embedded in new discoveries in central and southeast Anatolia (e.g., Özdoğan, Başgelen 1999; Lichter 2005). While field investigations of the early Holocene in western Turkey have increased considerably since then, with a few exceptions (e.g., Franchthi Cave, Knossos, Paliambela, Youra Cave, Maroulas) fieldwork in Greece stagnated. The archaeological community working in Greece focused instead more on detail, but crucial studies on a micro-level highlight the complex trajectories and adaptation process, particularly regarding early Holocene material, involving profound social, demographic, cultural and economic changes (e.g., Perlès 2001; 2003a; Séfériadès 2007; Kotsakis 2003; Souvatzi 2008; Trandalidou 2003; Galanidou 2011; Reingruber 2011).

This brief overview explains the different chronological and cultural concepts as well as the diverse available data sets for the first millennia in the Holocene in Aegean Greece on the one hand, and in western Turkey on the other. The dialectic research tradition of both regions handicapped their compre- 
hensive integration, especially with our longue durée perspective on the topic. Thanks to several new studies that overcome this artificial segregation, we are now able to combine various results and new data (e.g., Lichter 2005; Özdoğan 2010; Perlès et al. 2013; Guilaine 2013; Cilingiroğlu, Cakırlar 2013; Weninger et al. 2014; Kotsakis 2014; Horejs et al. 2015; Carter et al. 2016; Horejs 2016; 2017; Koztowski 2016; Cilingiroğlu 2016; Reingruber 2017; Milic 2018; Brami, Horejs in press). The Aegean coastal zones of modern Greece and Turkey are slowly coming together again as Mesolithic-Neolithic research re-evaluates both old and new concepts about the crucial early Holocene cultural developments.

\section{The Aegean Mesolithic: Time of foragers, fish- er(wo)men and seafarers}

The time between 9000 and $7000 \mathrm{BC}$ in the Aegean is characterized by mobile and seasonally based foragers (recently: Reingruber 2017). Our current knowledge is based on about 20 known sites along the Aegean coasts and on the islands, including Crete and the southern coast of Turkey (Fig. 1).

Thanks to studies and fieldwork by various scholars, the main cultural components of the Aegean Mesolithic in the $9^{\text {th }}$ and $10^{\text {th }}$ millennia BC were slowly brought to light with respect to the economy, mobility, exchange, resource management, technologies and other aspects, although many questions are still open and require more primary data (Galanidou, Perlès 2003; Galanidou 2011; Sampson 2010; 2014; Perlès et al. 1990; Kozłowski 2016; Reingruber 2011; 2017; Carter et al. 2016). In summarizing the main conclusions of Mesolithic research, we are faced with the remains of mobile groups who probably based themselves in seasonal camps. The Aegean islands appear to have been visited and used seasonally but intensively by foragers and fishermen, as attested at a few sites. A multi-seasonal or even yearround occupation of island sites is attested, such as on the islands of Youra, Naxos, Ikaria, Kythnos and Crete (Sampson et al. 2010; Strasser et al. 2010; Carter et al. 2014; 2016). We can assume the use of other islands and sites as well, which today lie below sea-level, as recognized for example at Youra (Efstratiou 2014. 79). Currently, early island occupation around the Pleistocene-Holocene transition is attested only in the northern Aegean, as at Ouriakos on Lemnos (Efstratiou et al. 2014). This picture may change, when more field data becomes available from the central and southern Aegean. The Mesolithic as currently known in the central and southern Aegean basin belongs mainly to the $9^{\text {th }}$ and $8^{\text {th }}$ millennia BC, also defined as the 'Aegean Mesolithic' (Kozłowski 2016).

A semi-sedentary lifestyle has been suggested for these societies based on the preserved architectural

\begin{abstract}
Fig. 1. The Aegean Mesolithic and western Anatolia Pre-Neolithic sites dating between 10000 and $7000 \mathrm{BC}$ and the Neolithic pioneer sites starting around $6700 \mathrm{BC}$ (after Horejs in press. Fig. 2 with modifications). 1 Ağacli; 2 Asarkaya; 3 Belbaşı; 4 Beldibi; 5 Calca; 6 Cyclops Cave (Youra); 7 Domaln; 8 Gavdos; 9 Girmeler; 10 Gümüşdere; $11 \mathrm{Kal}$ kanli; 12 Karain; 13 Kecicayırı; 14 Kerame; 15 Klissoura; 16 Koukou; 17 Livari; 18 Maroulas; 19 Mordoğan; 20 Musluceşme, 21 Öküzini; 22 Ouriakos; 23 Plakias; 24 Sidari; 25 Theopetra; 26 Ücdutlar; 27 Uğurlu; 28 Ulbrich; 29 Zaimis (map made by M. Börner, OREA).
\end{abstract}


remains. The best example is Maroulas on Kythnos, which is dated to the first half of the $9^{\text {th }}$ millennium BC. Circular and oval structures with stone pavements and enclosures, partially constructed with stone-tiles at the bottom, are reconstructed as huts with central posts and structured entrance areas (Sampson 2010.102, Figs. 98-101). About 27 of these dwellings represent at least a multi-seasonal occupation and are used for domestic activities (Sampson et al. 2010; Kozłowski 2016). Burials underneath the stone pavements of these huts and next to it represent a group of six children and 19 adults.

The economy of the Aegean Mesolithic was based on a subsistence strategy in which foraging played an important role alongside fishing of coastal and seasonal off-shore fish, including tuna. The evidence of grinding stones at Maroulas indicates the intensive use of plant foods processed at the site. The presence of pre-/semi-domesticated or domesticated pigs and caprines at Cyclopes Cave and Maroulas in Mesolithic times, as suggested by Katerina Trantalidou (2003; 2010), is based on very scarce data and viewed sceptically by various scholars (e.g., Kozłowski 2016). Neither species is local and both have to be brought to the islands by people (Trantalidou 2011). If the early evidence is affirmed by additional evidence and further analyses, the introduction of domesticates into the Aegean would have taken place at about the same date as their appearance in Cyprus (Vigne et al. 2012; 2014). Whatever the situation concerning the introduction of certain species, based mainly on results from Maroulas and the Cyclopes Cave (Trandalidou 2011), the economy of the island populations is based mainly on marine fishing and foraging, hunting birds as well as gathering snails. Finally, the lithic industry of the Aegean Mesolithic seems to be its own technological complex, based on a flake industry, with retouched flakes, splintered pieces, backed blades and microliths $(\mathrm{Ka}$ czanowska, Kozłowski 2008; Koztowski 2016). Recent investigations on the Aegean coast of Turkey revealed the new open-air site of Mordoğan on the Karaburun Peninsula near Izmir, which shows the same kind of industry (Cilingiroğlu et al. 2016). Ciler Çilingiroğlu has convincingly argued for an Aegean Mesolithic complex that includes the Anatolian coastal zone (Cilingiroglu 2016), and she now offers the first evidence of a Mesolithic population in the centre of the Aegean coast of Turkey.

The evidence for intensive Mesolithic seafaring in the Aegean Sea implies highly connected mobile groups, occupying sites on the islands and partially also the shores at least multi-seasonally, partially perhaps also round-year. A network of voyaging groups is indicated by the intensively used obsidian from sources on Melos and Giali (Ammermann 2014) (Fig. 1). Although we have no information on their communication systems, and are far from a detailed resolution of the chronological situation of the Aegean Mesolithic, the agents of the obsidian exploration offer us a small indirect insight into these societies. The knowledge of both island sources had to be transmitted down the generations and between groups. This information had to be embedded in a whole package of nautical knowledge including the routes, navigation, winds and currents, seasonal weather conditions, landing options, available water sources, transport facilities and much more (Broodbank 2013; Cherry et al. 2017). It is therefore safe to assume that these maritime societies not only developed a distinct system of mobility in their marine environment, but also established a package of nautical knowledge as a fundamental Mesolithic capability that was sustained over many generations.

These Mesolithic Aegean networks seem to come in contact with the eastern Mediterranean, at least sporadically (e.g., Horejs et al. 2015; Kozłowski 2016). These contacts are indicated by some elements adopted in the Mesolithic Aegean that most probably came from Cyprus and the Levant, as recently argued by Kozłowski (2016). These are the circular dwellings with stone foundations and floors, burials underneath the floors and next to the dwellings, evidence of grinding stones and plant processing as well as a few stone vessel fragments. Another potential side-effect of these contacts between the Aegean Mesolithic and Cyprus is seen in some aspects of the stone industry, which is interpreted as a potential western influence on Cyprus (Ammerman 2014; Koztowski 2016). It has been suggested (Kaczanowska, Koztowski 2014) that the lithic assemblage of Nissi Beach, based on a pebble-flake industry and the production of certain tools such as arched-backed pieces, denticulates, and notches, may be evidence for close connections between Cyprus and the Aegean Mesolithic. The seafaring groups of the Aegean Mesolithic had certainly established maritime networks in the $9^{\text {th }}$ millennium $\mathrm{BC}$, which appears to coincide with the existence of the eastern Mediterranean maritime network.

We are therefore faced with an Aegean Mesolithic society organized in mobile groups and based on a foraging, fishing and hunting economy, which stands in strong contrast to the contemporaneous Pre-Pot- 
tery-Neolithic cultures of the Levant and central and southeast Anatolia. Aside from the few presumably adopted elements mentioned above, the economic, cultural and social characteristics of the PPN societies are not evident in the Aegean Mesolithic (Fig. 2). Although the mobile or semi-mobile populations of the Aegean islands and the littorals came into contact with the PPN societies of Cyprus and the Levant, the direct transfer of the classic Neolithic village society and farming economy is not recognizable in the $9^{\text {th }}$ and $8^{\text {th }}$ millennia BC. Neither the complex early PPN symbolism nor the practice of farming, herding and sedentary settlements is to be found in the Aegean Mesolithic. Indeed, one may wonder why and how a population with an established economic niche system founded on a maritime mobility, resource system and subsistence strategy should integrate and adopt the new Neolithic strategies into their way of life. The island environmental conditions offer the ideal world system for the Aegean Mesolithic maritime societies, and are not at all suitable for farming, herding or permanent settlement. It is therefore not surprising that the first year-round Neolithic farmers on the islands (as distinct from the mainland coasts) are a quite late phenomenon, not arriving before $6^{\text {th }}$ or even $5^{\text {th }}$ millennia BC. Even after the establishment of the Neolithic in the surrounding coastal zones of the Aegean in the early 7 th millennia BC, the new economic system did not reach the islands immediately. Crete, as the largest Aegean island, is the only exception, where an early Neolithic economy is attested at Knossos in the early $7^{\text {th }}$ millennium BC (Douka et al. 2017). However, the Knossos pioneer phase did not lead to a dispersal of farming and herding communities in Crete, and it appears to have lasted for only a short time at Knossos. The Neolithic at Knossos succeeded only after a hiatus of about 1000 years, probably again related to the incoming of new people, as recently suggested by Katerina Douka et al. (2017).

If an interaction existed between the mobile maritime foragers and the Neolithic farmers in the $7^{\text {th }}$ millennium BC, how it may have operated, and how long both systems might have existed in parallel, is unfortunately unknown. At least in the $9^{\text {th }}$ and $8^{\text {th }}$ millennia BC we are confronted with two different cultural world systems, an Aegean Mesolithic on the one hand, and a Neolithic in the 'core zones' of Southwest Asia on the other hand, with well-established and long-term seaborne contacts preparing the foundations for the later Neolithic dispersal (Broodbank 2013; Simmons 2014; Horejs et al. 2015; Dou$k a$ et al. 2017).

\section{Western Anatolia in Pre-Neolithic times}

Thanks to new investigations in northern, central and southern areas of western Anatolia, the scattered data of the Pre-Neolithic is slowly coming together, although many questions remain un-answered. Based on current data, around 15 sites probably dating between $10000 \mathrm{BC}$ and the beginning of the Neolithic at around $6700 \mathrm{BC}$ are spatially clustered on the coast of western Anatolia. This clustering probably reflects the regional distribution of surveys and field investigations. The higher sea level and the related geographical and climatological settings in the Younger Dryas and early Holocene revealed a closer proximity between the northeast Aegean islands of Gökçeada, Bozcaada, Lesbos, Lemnos and Samothrace, as well as to the Gallipoli Peninsula. While they were presumably still connected with the mainland in the Older Dryas about 16000 years ago, the Pleistocene sea level rise led to the islands' setting and the increasing distance between them and the mainland (Özbek, Erdo ̌̆u 2014). The lithic assemblages - though still based on a few sites show that the landscape of the Bosporus northern shore as well as the Marmara coastal zones in the south and the Gallipoli Peninsula including the island Lemnos were used in Epi-Palaeolithic and Mesolithic times (Gatsov, Özdoğan 1994; Efstratiou et al. 2014). Moreover, a clear chronological distinction based on survey materials is currently not possible (Milić 2018); the so-called Ağaçlı Group in northwest Anatolia might represent the remains of mobile pre-Neolithic societies, while the other surveyed sites in Çanakkale and Balıkesir provinces may attest the initial movements of so-called 'forerunners' of the Neolithisation taking place in the region (Özdoğan 2008; 2011). The flake-based lithic industry of Üçdütlar might give us a first indicator for potential connections to the Aegean Mesolithic (see above), although they do not appear comparable based on the current state of knowledge, as summarized by the experts (Özbek, Erdoğu 2014).

The southwest Anatolian coastal littoral and its wider hinterland provide new evidence of semi-mobile or even permanent foragers and hunter communities in the Girmeler Cave (Takaoğlu et al. 2014). Their remains of plastered floors and dwellings with hearths and pits suggest the continuous use of a site where domestic activities took place. Though based on a complete hunting and foraging economy, plant processing is indicated by grinding stones, as also known from the contemporaneous Aegean Mesolithic. The late $9^{\text {th }}$ and $8^{\text {th }}$ millennia $\mathrm{BC}$ site might 
represent only the tip of the iceberg of terrestrial hunter-foragers in the region. The $8^{\text {th }}$ millennium $\mathrm{BC}$ sequences of plastered floors have been related to inner Anatolian PPN traditions, such as those best presented in Aşıklı (Takaoğlu et al. 2014). As recently suggested by Çilingiroğlu (2016), the hunter-gatherers of Öküzini Cave probably reflect early forager-farmer interaction related to the pioneers who founded the first Neolithic farming sites in the Aegean in the period between 7000 and $6600 \mathrm{BC}$. So far, there is no evidence for the earlier adoption of domesticated crops and herded animals. As in the Aegean Mesolithic, we might imagine terrestrial hunter-foragers with probable contacts to central Anatolia on the one hand, and to the Aegean Mesolithic groups on the other hand. The southern coast of Anatolia should play a particularly crucial role in our understanding of the Neolithic dispersal, but till now early farmers and herders have not been detected, although in my view they can be expected to exist and are still awaiting discovery. The more inland sites around the Lake District (like Bademağacı and Höyücek) are not directly connected to the coast, and most probably date a few generations later than the pioneer groups coming along the southern Anatolian coast (Clare, Weninger 2014.11). The recently detected site with a Mesolithic flake-based lithic industry in Mordoğan on the Karaburun Peninsula mentioned above provides the first evidence for hunter-foragers on the central Aegean coast of Turkey. The first studies of the surface materials pinpoint the strong relations to the Aegean Mesolithic in a raw material and techno-typological sense ( $\mathrm{Ci}$ lingiroğlu et al. 2016). Although we await future analyses of the site's chronology and economic data, evidence of hunter-foragers (and probably also fishermen) can be expected for the Izmir region as well.

How these early Holocene hunter-foragers of western Anatolia were culturally connected to the PPN farmers and herders of the 'core zone' further east remains an open question. So far, we can recognize some influences in cultural practices, such as the plastered floors in the southwest mentioned above, also interpreted as an indicator of a sedentary lifestyle. But the most essential economic foundation for sedentism - farming and herding - was not adopted by these communities for a long time. The western Anatolian hunter-foragers between 10000 and 7000 BC apparently lack any transformation or experimental phases in their economy. The adopted socialcultural techniques, such as (wild) plant processing and the erection of dwellings, might reflect occasional contacts with the Neolithic in the east, and highlight a potential long-term connectivity in these millennia that prepares the ground for the arrival of the new social and economic strategies of the Neolithic a little after 7000 cal BC.

\section{Similarities and differences in the early Holo- cene}

Overall, the Aegean Mesolithic and the Pre-Neolithic western Anatolia offer a heterogeneous picture in the early Holocene, with lots of unknown aspects regarding their populations in these millennia. Nevertheless, the currently available data allows us to note some similarities and differences, which I will try to summarize without over-simplifying a complex story covering about three millennia. The main common feature is to be seen in their economic strategies, which remain connected to mobility and differ in relation to distinct environmental conditions. Together with foraging, hunting of small animals on the Aegean islands and of large mammals on the mainland in Greece and Turkey forms the economic backbone. The important role of fishing for the island economies is also attested for coastal communities, as in the fishing at Franchthi or shell collecting in Üçdütlar (Rose 1995; Perlès 2003b; 2019; Stiner, Munro

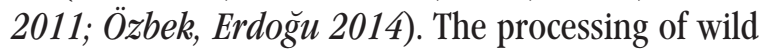
plants is another common economic aspect, indirectly evident by the use of grinding implements. The erection of huts and dwellings with floor-sequences indicating potential permanent or at least repeated use is known from a few sites in the vast area. Although contacts with the Neolithic economies in the eastern Mediterranean and inland Anatolia are indicated, their farming subsistence systems were not adopted either in western Anatolia or the Aegean before about $6700 / 6600 \mathrm{BC}$. The Aegean and western Anatolian hunter-foragers appear to have continued their long-established subsistence practices without any evidence of transformation, experimentation or adaptation to farming or herding. Finally, the almost complete lack of symbolism remains astonishing in relation to the complex symbolic systems of the neighbouring PPNs world (Fig. 2).

However, the absence of any symbolic material does not imply communities without a multifaceted system of beliefs. Rather, the lack of evidence confronts us with the problematic visibility of these aspects in early Holocene hunter-forager-fishing societies.

The differences between the regions can be recognized in the lithic technologies, raw material procurement (local versus non-local) and some cultural 
practices (e.g., plastered floors, burials), which are expected to increase in respect of the number and types of differences with more data in the future. Finally, the concept of the Mesolithic as a culturally and chronologically defined period is widely accepted in the Aegean and on the Greek mainland, related to continental European research history (e.g., Perlès 2019). The western Anatolian sites are strongly connected with the Near Eastern tradition, where the Epipaleolithic before the early PPN period is a well-established cultural concept (Watkins 2018). The merging of both research traditions in western Turkey reflects the complexity of late Pleistocene/ early Holocene archaeology in the region. Both concepts - Epipaleolithic in the Near Eastern and Mesolithic in the Aegean case - are currently applied to western Anatolian sites. Future studies will hopeful-
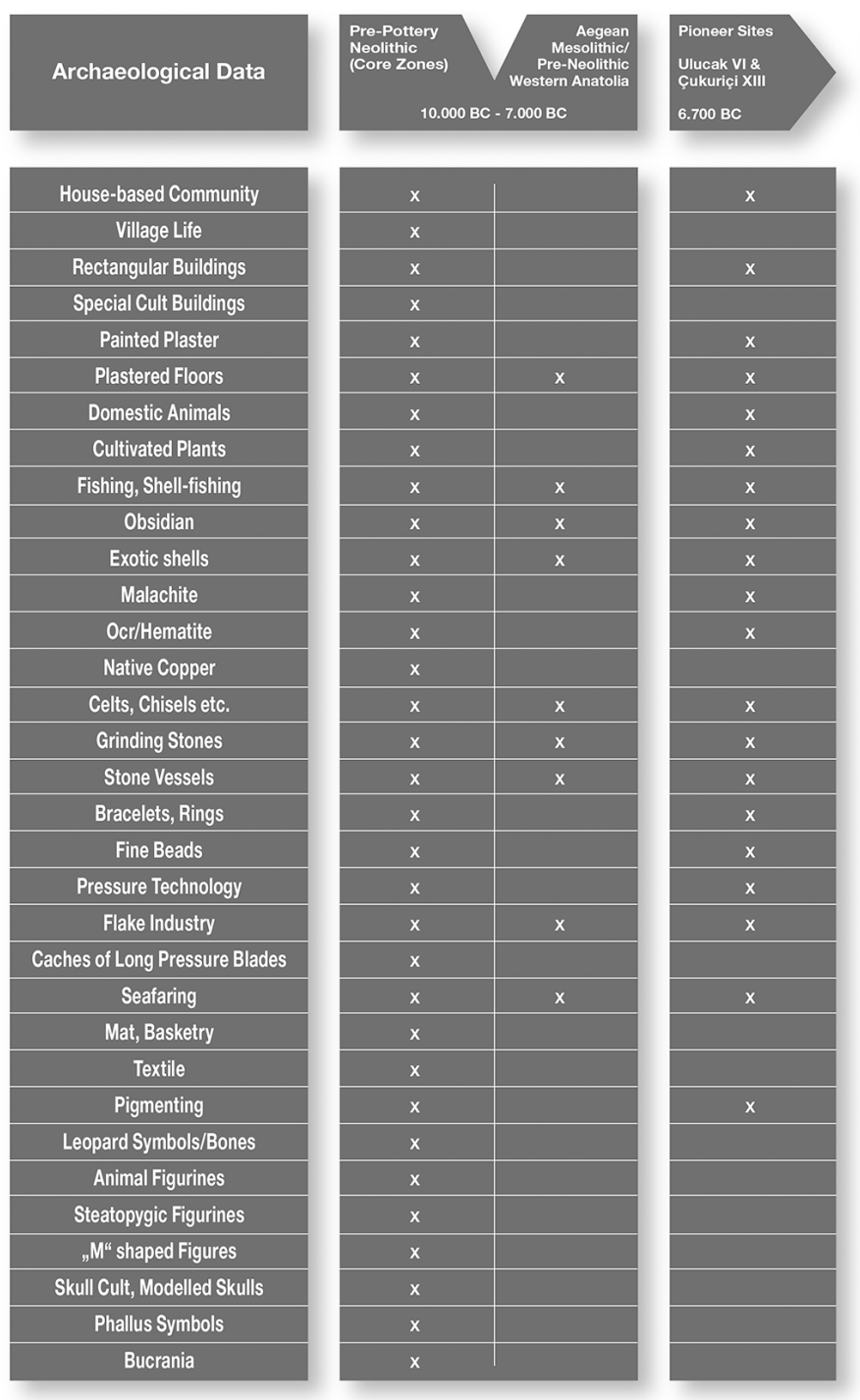

Fig. 2. Archaeological evidence of the PPN Core Zones, Mesolithic Aegean/ Pre-Neolithic western Anatolia, Neolithic Pioneers and the Anatolian Aegean Coastal Group (table made by F. Ostmann, OREA after Özdoğan 2010.Tabs. 1-2).
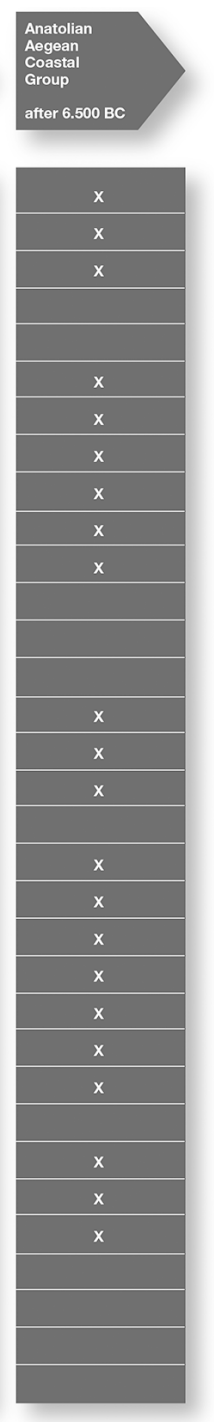

ly show the expected high number of regional differences and how potential cultural varieties can be interpreted to gain a deeper insight into the populations before the fundamental change into the Neolithic way of life took place.

\section{The abrupt arrival of the Neolithic}

The Neolithic way of life appears to start abruptly in the Aegean and in western Anatolia, already fully developed in all main aspects, such as farming, herding and sedentary life (Fig. 2). A few sites around the Aegean Sea and in inland western Anatolia represent the first Neolithic farming communities, recently defined as pioneers (Horejs et al. 2015): Barcın Höyük, Ulucak, Çukuriçi, Uğurlu, Knossos, Franchthi and perhaps Paliambela (Fig. 1). They all date within the timeframe of 7000 to $6600 \mathrm{cal} \mathrm{BC}$; unfortunately a more precise date cannot be achieved due to a plateau in the current radiocarbon calibration curves. Site-based modelling revealed the most probable date for most of these sites is around $6700 \mathrm{cal} \mathrm{BC}$ (Weninger et al. 2014; Perlès et al. 2013; Horejs et al. 2015; Brami, Zanotti 2015; Maniatis 2014; Douka et al. 2017; for a different modelling see Guilbeau et al. 2019). However, we are currently aware of only a few early Neolithic sites founded before $6600 \mathrm{cal}$ $\mathrm{BC}$, whereas the majority of Neolithic farming sites developed after this. The first appearance of these early farmers in diverse landscapes and environments, such as the Aegean littorals, the Gökçeada Island and the Marmara Sea in western Anatolia, as well as diverse cultural contexts, suggests different trajectories.

Although we have to take into account the likelihood of diverse processes, the abrupt appearance of farming and herding societies suggests a general pattern of Neolithic expansion, as stated often and by se- 
veral scholars (e.g., Perlès 2003a; Özdoğan 2011; 2014; Guilaine 2013; Weninger et al. 2014; Brami, Zanotti 2015; Brami, Horejs in press). The pioneer sites around the Aegean Sea were most probably founded by newcomers and brought the new Neolithic subsistence strategies (as well as the animals and plants) together with other social and cultural elements (Fig. 2). This pioneer phenomenon, also described as the 'maritime colonization model' ( $\mathrm{Ho}$ rejs et al. 2015), may over-simplify the initiation of a complex process beginning immediately after the arrival of new groups, involving interactions between the newcomers and indigenous groups, and adaptation to local environmental conditions (recently Guilbeau et al. 2019). Further, the process of groups from different origins searching for new land over a period of several centuries can hardly be summarized as a singular event. This is apparent in inland Anatolia, as well as for Crete and Cyprus, where several waves of moving groups are evident (Özdoğan 2008; Vigne et al. 2012; Douka et al. 2017).

The Aegean pioneer sites show crucial economic and social aspects in common that clearly belong to the earliest Neolithic lifestyle in our region, and stand in strong contrast to the earlier Aegean Mesolithic. These new Neolithic aspects are four-tier husbandry, the planting of domestic cereals and pulses, permanent habitation in house architecture and new material-related technologies (Fig. $2 ;$ e.g., Cilingiroğlu 2016). The whole bundle of innovations - the 'Neolithic package' - is related to a broader package of skills and knowledge affecting all crucial aspects of individual and community life. To start with, there was a new way of life in rectangular mud-built houses, as at Çukuriçi XIII, Ulucak VI and probably also in Knossos X. As Çilingiroğlu (2016) has recently pointed out, the technology of lime-plastered floors is limited to Anatolian mainland sites (continuing through the later stages of the Neolithic), as seen at Cukuriçi, Ulucak, Bademağaçı and Hacılar, and is not found on the Greek mainland or on Crete. This regionally distinct phenomenon may indicate different origins; the evidence of plaster in floor-sequences at the Pre-Neolithic Girmeler Cave in southwest Anatolia (Takaoğlu et al. 2014) points to the probable route along the Anatolian coast and the incorporation of the $9^{\text {th }}$ and $8^{\text {th }}$ millennia BC foragers into both inland Anatolian and maritime networks. Red plaster appears to be restricted to the foundation horizons of the pioneer sites, as attested in Ulucak VI and Çukuriçi XIII. The deposition of red lumps inside the Çukuriçi XIII house additionally supports the practice of using this pigmenting technology by the early settlers. As Çilingiroğlu convincingly argues, the use of red plaster found no place among the Epipalaeolithic hunter-gatherers of Southwest Asia, but is characteristic of later Pre-Pottery Neolithic settlements. The houses of the early pioneers were the centres for domestic activities, evident in food processing, storage and fire installations such as hearths. This new kind of architecture included sequences of floors, which indicate permanent occupation and periodic renewal; the material evidence shows us that these were house-based societies representing a new form of social life. The restricted extent of the excavated area of the earliest levels at almost all the pioneer sites is a limiting factor preventing any kind of population estimate; we cannot definitely describe them as early 'villages'. The concept of Neolithic villages is currently not attested before $6600-6500 \mathrm{BC}$ (Fig. 2). Rather, we are probably dealing with small groups of pioneers, living together in house-related communities. While this general pattern is attested at the western Anatolian sites (Ulucak VI, Çukuriçi XIII) and probably also in early Knossos, the pioneers of the same period in the northern Aegean, evident in Paliambela, initially practiced a different settlement strategy based mainly on pit structures (Maniatis 2014; Katsanis et al. 2008). The excavation analyses by Kostas Kotsakis and his team will show if these pit complexes represent local adaptations of the new social life, or served as the initial stages of a semi-mobile or permanent habitation strategy, representing another trajectory within the wider dispersal.

\section{Subsistence strategies mark the new Neolithic economy}

The pioneers' subsistence was based on a fully developed farming and herding economy with many essential details in common. It has frequently been pointed out that the four domesticates - sheep, goat, cattle and pigs - are evident in most of the pioneer sites, as for example at Franchthi, Knossos, Çukuriçi and Ulucak, and represent a series of complimentary sets of developed herding strategies (e.g., $A r$ buckle et al. 2014; Horejs et al. 2015; Munro, Stiner 2015; Cilingiroğlu 2016). The evidence of a comparable economy at Bademağacı and Uğurlu $\mathrm{V}$ dates slightly later, and is probably not related to the earliest introduction (Clare, Weninger 2014; Atrcr et al. 2017). Although the wild ancestors of domesticates are evident at least as far west as the Aegean coast of Anatolia and the island of Gökçea$\mathrm{da}$, the stock-keeping economy is complete and pre- 
sent from the beginning, with no experimental or transformation phases (Cakırlar 2012; Galik, Horejs 2011; Horejs et al. 2015; Galik in press). Benjamin S. Arbuckle et al. (2014) have argued convincingly for the dispersal of the four-part herding economy along the Mediterranean coasts, bypassing central Anatolia (where cattle and pigs are not evident). The lack of domesticated pigs at the pioneer site of Barcın Höyük in northwest Anatolia and in the later dated Uğurlu $V$ gives additional support to this model; instead, in the earliest phase of Barcin Höyük wild boar were hunted (Arbuckle et al. 2014; Gerritsen, Özbal 2016; Atıcı et al. 2017). New zooarchaeological and stable isotope data from Uğurlu $\mathrm{V}$ in the northeast Aegean are suggesting a founder population of the sheep and goat stock from the mainland, or at least from more arid zones than the western Anatolian coast (Pilaar Birch et al. 2019). The Çukuriçi sample highlights an additional economic aspect of the stock-keeping and farming community related to maritime sources. From the founding of the site onwards fishing and diving for shells played an important role in providing nutrition ( $\mathrm{HO}^{-}$ rejs 2012; Horejs et al. 2015; Galik, Horejs 2011; Galik in press). Inshore fish, such as sea bream, sea bass, groupers and bluefish, as well as pelagic fish like tuna and chondrichthyes (stingray), are evident (Fig. 3).

A variety of bivalves, like lagoon cockles, corneus wedge clams, venus shells, carpet shells, noble penshells, ark clams, bearded ark clams, mussels, oysters, spondylus, date shells and paddocks as well as a wide variety of marine gastropods are attested in the assemblage. These indicate different practices of collecting, diving and fishing with distinct equipment, experience and knowledge of seasonal conditions. The role of fishing in the former Aegean Mesolithic economies has been discussed above and is evident in fish remains (e.g., Franchthi) as well as in fishing equipment, like hooks (e.g., Youra). The maritime exploitation skills might indicate a knowledge transfer from or even an adaptation process of local Aegean economies by the Neolithic newcomers. They may have brought fishing expertise with them, bearing in mind the evidence in Neolithic Cyprus (Vigne et al. 2014). Overall, hunting was practiced only in small amounts and herding dominates the economy in the Neolithic pioneer sites. Cultivation of crops is evident at the pioneer sites, but published data is still rather scarce and it is difficult to form a clear picture (Cilingiroglu et al. 2012; Perlès et al. 2013; Horejs et al. 2015). The botanical analyses of Ulucak, Franchthi and Cukuriçi reveal heterogeneous data of einkorn and emmer wheat, barley, free-threshing wheat and pulses.

\section{New technologies and exotic items}

A package of new lithic technologies and distinctive tools is attested at some of the Neolithic pioneer sites (Milic 2018; Milic, Horejs 2017; Guilbeau et al. 2019). Most important is the use of pressure-flaking technology in producing chipped stone tools, mainly blades and bladelets, which is absent before 6700 BC. The flake-based industry of the Mesolithic Aegean, as well as the diverse technological industries in PreNeolithic western Anatolia, appear to continue, but are first supplemented and soon afterwards dominated by pressure blade making (recently Guilbeau et al. 2019). Together with the adoption of a new production technique, some atypical tool types like lunates and foliate points (not known in the Mesolithic Aegean) appear in the founding phase of the pioneer site Çukuriçi Höyük XIII. The whole lithic package indicates an origin in the east Mediterranean, the Levant and north Mesopotamia, and probably represents the arrival of lithic industries from outside the region (Perlès 2001; Horejs et al. 2015; Milic 2018). A few other objects in the material assemblages of the newcomers' sites around the Aegean Sea seem to incorporate narratives, materials and technologies that cannot be related to the local traditions of the Mesolithic Aegean (for earlier ornaments see Perlès 2019). As recently recognized by Çilingiroğlu (2016.36), the very few symbolic items and special objects in the early Neolithic are all por-
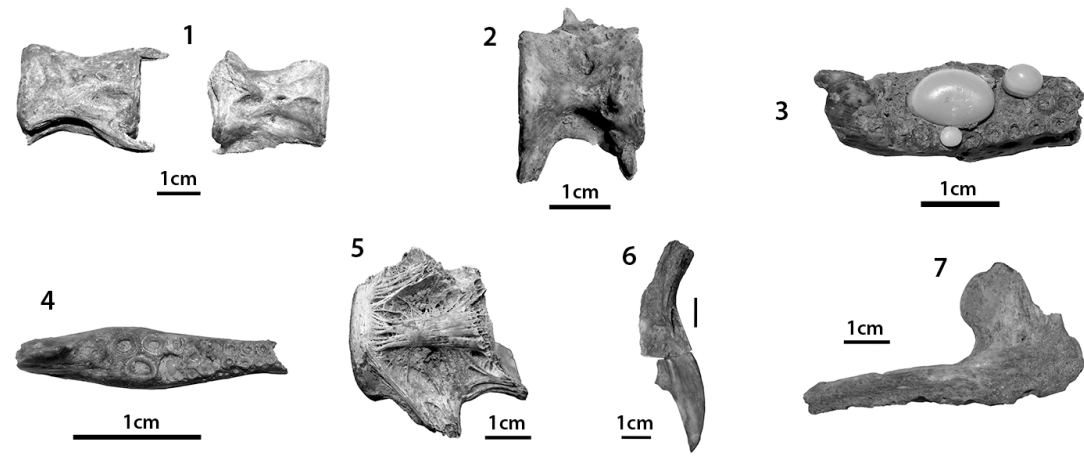

Fig. 3. Neolithic fish bones from Cukuriçi Höyük representing the variety of species hunted regularly. 1-2 tuna; 3 gilthead seabream; 4 striped seabream; 5-6 grouper; 7 bluefish (classification and photos by $A$. Galik, figure design by F. Ostmann/OREA). 
table. The well-made stone bracelets (Çukuriçi and Knossos), a malachite bead (Çukuriçi), and pierced circular beads (Ulucak and Çukuriçi) are rare finds; they appear exotic in the Aegean and may have arrived with the newcomers, or via extensive exchange networks (Horejs in press).

The evidence of ceramic vessel production in the pioneers' founding phases is either very rare or completely lacking, as pointed out several times (Perlès 2001.83; Reingruber 2015; Horejs et al. 2015; Cilingiroğlu 2016; Douka et al. 2017). Pottery production does not play any role at the beginning of this process, especially in the coastal sites of the Aegean Sea, where it is totally lacking in Ulucak VI and evident only as small fragments potentially representing later intrusions in Çukuriçi XIII. The impact of ceramics appears different in Barcin Höyük, a pioneer site at the southern Marmara Sea, where pottery containers are evident from the beginning (Gerritsen et al. 2013; Gerritsen, Özbal 2016; de Groot et al. 2017). The early practice of pottery-making perhaps points to the Marmara Sea pioneers' relation to central Anatolia, where the presence of a much longer ceramic tradition has recently been argued (Fletcher et al. 2017).

An overview of all the archaeological data regarding settlement and architecture, subsistence, imported raw materials, ground-stone tools, status objects, lithic technology, special crafts and symbolic representations illustrates the abrupt arrival represented by the pioneer sites of Ulucak VI and Çukuriçi XIII (Fig. 2). The integration of Mesolithic Aegean and Pre-Neolithic western Anatolian evidence into this overview clearly demonstrates that only very few aspects of the new Neolithic social life can be attested in our region before the arrival of the newcomers.

\section{The long and short revolutions}

The paradox of a short revolution within the longterm process of the Neolithisation can probably be related to the distinct cultural conditions in the Aegean Mesolithic and the Pre-Neolithic western Anatolian world(s), where the idea of a long revolution is hardly tenable on present evidence. The long-established hunter-forager-fisher communities of the early millennia of the Holocene seem to encounter the contemporary farmers and herders in inland Anatolia, as well as via maritime networks. A few cultural practices (e.g., plastered floors, stone vessels) indicate potential forager-farmer interactions within terrestrial Anatolia, such as between Cappadocia and the coastal zones of southwest Turkey (Fig. 2). The implementation of (wild) plant processing with grinding stones within the subsistence strategy of those Pre-Neolithic societies probably reflects knowledgetransfer and adaptation based on these contacts via terrestrial and maritime routes. The impact of this interaction on the hunter-forager-fishers presumably included other social-cultural aspects as well, which are not visible in the archaeological record. The evidence of semi-sedentary habitation with dwellings of multi-seasonal or even permanent use might reflect a crucial shift in the cohabitation of the communities. The evidence of such dwellings and floor-sequences are usually seen as Neolithic influences (Sampson 2010; Takaoğlu et al. 2014; Kozłowski 2010). Further analyses and new field data will perhaps indicate whether the adoption of a semi-sedentary lifestyle did in fact lead on to house-based communities before $7000 \mathrm{BC}$. The lack of evidence for this is not surprising in the context of the economic background, in which mobility played a crucial part, at least for the maritime communities of the Aegean. The distinctive Aegean Mesolithic system of seasonally mobile groups, using their environmental conditions in a highly specialized and sustainable way, appears unsuited to the adoption of farming and herding strategies.

The economic system of Pre-Neolithic western Anatolia differed in many aspects and could therefore more easily integrate new subsistence strategies. The founding of the first farming and herding communities on the mainland of Greece and western Turkey took place in areas well suited to agriculture, in areas generally different from the formerly used peninsulas or caves (with the exception of the Franchthi Cave, where an initial Neolithic is evident). The coastal zones of southwest Anatolia, which have been only sketchily investigated thus far, are likely to offer new data on pioneers in the future, and possibly for older occupations than those presently known. The interactions via overland and maritime routes may indicate a long-term process of communication between hunter-foragers and farmers, involving the adoption of a few cultural and subsistence practices and some related ideas, technologies and perhaps also worldviews. The suggested exploration phase by sea and land may form a crucial first stage in a longue durée process (Özdoğan 2010; Broodbank 2013; Horejs et al. 2015; Cilingiroğlu 2016). The archaeologically invisible seafaring and travelling groups searching for new land and new options are hardly a singular event in time. We can envision a continuous and ongoing process of small-scale mi- 
gration, which is observable at Knossos (Douka et al. 2017). It is in this short revolutionary perspective that the first farming and herding communities appear after $7000 \mathrm{BC}$. This sudden appearance of more or less contemporaneous settlements is on the one hand an abrupt event occurring between 7000 and $6600 \mathrm{BC}$, which on the other hand marks the end of a long-term process of exploration, communication, knowledge-transfer and adaptation. The paradox of this 'sudden event' within the long revolution process has been argued as resulting from maritime and terrestrial colonization by Neolithic pioneers (Broodbank 2013; Horejs et al. 2015; Douka et al. 2017).

Recent genetic studies additionally support this colonization model (Hofmanová et al. 2016) by demonstrating close relations between the agricultural communities in Anatolia, Greece and continental Europe with common ancestors (recently Lazaridis et al. 2016; Mathieson et al. 2018). These new genetic data convincingly demonstrate the movement of people from Anatolia into Europe during the intensification phase of the Neolithic (Mathieson et al. 2018), although timespan, frequency, and not at least potential 'origins' are still matter of debate. The origins within the core zone may be several and various, differing between the regions of inland western Anatolia and the Aegean littoral. More detailed studies of the material relations of Franchthi (Perlès 2005) and Cukuriçi (Horejs et al. 2015; Milic 2018) indicate a starting point in the eastern Mediterranean (including the Levant and north Mesopotamia), at least for those two pioneer sites. Movement of people is therefore the current best-fitting model for the Neolithisation of the Aegean and western Anatolia according to both the archaeological and DNA data in my view (for a different view s. Guilbeau et al. 2019). The trigger for these developments remains an open question and our model requires further research (Brami, Horejs in press).

Since the first farmers and herders arrived in the region after $7000 \mathrm{BC}$, the dispersal within the Greek mainland, the Aegean littorals and within western Anatolia took place within a few generations (with the exception of Crete). The next generation of farmers extended their activity zones, cultivated various new micro-regions and were living in house-based communities embedded in village-based systems. From 6500 BC onwards, an increase in settlements seems to reflect a demographic boom (see Shen- nan et al. 2013 for the phenomenon in continental Europe). Regional groups emerged with their own identities, as the Anatolian Aegean coastal group demonstrates (Horejs 2016). Various settlements in this micro-region over some 500-700 years shared economic strategies, means of raw material procurement and distribution, socio-cultural practices, the style and technology of pottery production and several other material technologies. These Neolithic communities continued some traditional aspects of subsistence and sourcing, such as fishing and shellfishing and obsidian exchange, both of which originate in the Mesolithic period (Fig. 2). The established Aegean obsidian networks seem to form the basis for the succeeding raw material exchange systems of the Neolithic village-based communities. Targeted seafaring based on well-established nautical knowledge and skills was integrated into the Neolithic system, as has been recently shown for the procurement of jadeite from the island of Syros (Fig. 4), with distribution reaching Çukuriçi in the $7^{\text {th }}$ millennium BC (Sørensen et al. 2017; Schwall et al. in press).

We do not know how long the hunting-foraging-fishing seafaring societies in the Aegean Sea continued to exist alongside the farming-herding communities. The newcomers may not have immediately affected their environmental conditions and related economic and social systems. While the new Neolithic life of the Greek mainland and western Anatolia increased rapidly among the succeeding generations of farmers and herders, for at least another millennium most of the Aegean islands remained untouched by these crucial cultural, economic and social changes.

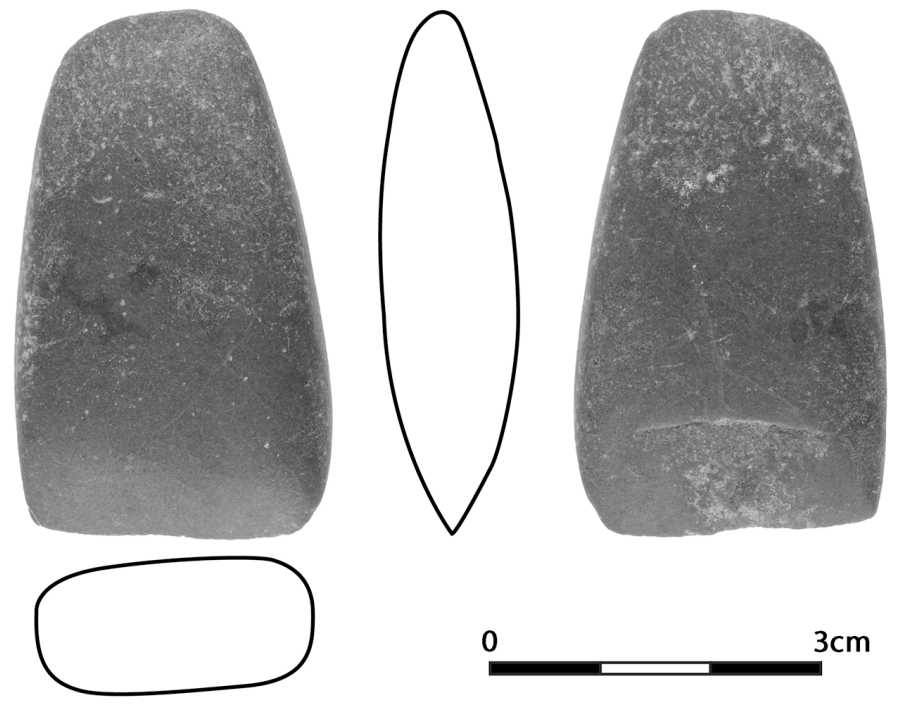

Fig. 4. Late Neolithic jadeite axe from Cukuriçi Höyük phase IX, Object no. 13/1722/3/2 (photos by N. Gail, graphics by M. Röcklinger/OREA). 
The paper was originally written in 2016 as chapter for a book about "The Long Revolution" initiated by Klaus Schmidt and Trevor Watkins years before, which could unfortunately not be realized. My sincere thanks go to all my colleagues involved in this project and especially to Trevor Watkins for his tremendous editing work, inspiring feedback during the meetings and his support to create a broader narrative. I would like to thank Bogdana Milic and Alfred Galik for crucial discussions and the whole Cukuriçi team for the engagement in our field work and ongoing data analyses. Many thanks are addressed to Felix Ostmann and Maria Röcklinger for the creation of the figures and to Mario Börner for designing the map. I am very thankful to the funding of our research by the European Research Council (ERC project 263339), the Austrian Science Fund (FWF projects Y528 and P25825) and the OREA institute of the Austrian Academy of Sciences. Finally, I thank Roderick Salisbury, Trevor Watkins and Clare Burke for English corrections at different stages of this manuscript.

\section{References}

Ammerman A. J. 2014. Setting our sights on the distant horizon. Eurasian Prehistory 11 (1-2): 203-236.

Arbuckle B. S. and 22 co-authors. 2014. Data sharing reveals complexity in the westward spread of domestic animals across Neolithic Turkey. PLOS ONE 9(9): e107824. https://journals.plos.org/plosone/article?id=10.1371/jou rnal.pone.0099845.

Atıcı L., Pilaar Birch S. E., and Erdoğu B. 2017. Spread of domestic animals across Neolithic western Anatolia: New zooarchaeological evidence from Uğurlu Höyük, the island of Gökçeada, Turkey. PLoS ONE 12(10): e0186519. https://doi.org/10.1371/journal.pone.0186519

Brami M., Heyd V. 2011. The Origins of Europe's First Farmers: The Role of Hacilar and Western Anatolia, Fifty Years on. Prähistorische Zeitschrift 86: 165-201. https://doi.org/10.1515/pz.2011.011

Brami M., Horejs B. (eds.) in press. The Central/Western Anatolian Farming Frontier. Proceedings of the Neolithic Workshop held at 10th ICAANE in Vienna, April 2016. Oriental and European Archaeology 13. Austrian Academy Science Press. Vienna.

Brami M., Zanotti, A. 2015. Modelling the initial expansion of the Neolithic out of Anatolia. Documenta Praehistorica 42: 103-116. https://doi.org/10.4312/dp.42.6

Broodbank C. 2013. The Making of the Middle Sea: A History of the Mediterranean from the beginning to the emergence of the Classical world. Thames and Hudson. London.

Çakırlar C. 2012. The evolution of animal husbandry in Neolithic Central-West Anatolia, the archaeozoological record from Ulucak Höyük (ca. 7040-5660 cal. BC, Izmir, Turkey). Anatolian Studies 62(1): 1-33. https://doi.org/10.1017/ S0066154612000014
Carter T., Contreras D. A., Doyle S., Mihailović D. D., Moutsiou T., and Skarpelis N. 2014. The Stelida Naxos Archaeological Project: New data on the Mesolithic and Middle Palaeolithic Cyclades. Antiquity 88(341). Project Gallery. http://journal.antiquity.ac.uk/projgall/carter341

Carter T., Mihailović D. D., Papadatos Y., and Sofianou C. 2016. The Cretan Mesolithic in context: New data from Livari Skiadi (SE Crete). Documenta Praehistorica 43: 87101. https://doi.org/10.4312/dp.43.3

Cherry J., Leppard F., and Thomas P. 2017. Patterning and Its Causation in the Pre-Neolithic Colonization of the Mediterranean Islands (Late Pleistocene to Early Holocene). The Journal of Island and Coastal Archaeology 13(2): 191205. https://doi.org/10.1080/15564894.2016.1276489

Clare L., Weninger B. 2014. The Dispersal of Neolithic Lifeways: Absolute Chronology and Rapid Climate Change. In M. Özdoğan, N. Başgelen, and P. Kuniholm (eds.), The Neolithic in Turkey 6. 10 500-5200 BC: Environment settlement, flora, fauna, dating, symbols of belief, with views from north, south, east, and west. Archaeology and Art Publications. Istanbul: 1-65.

Çilingiroğlu A., Çevik Ö., and Çilingiroğlu C.. 2012. Ulucak Höyük. Towards understanding the early farming communities of Middle West Anatolia: the contribution of Ulucak. In M. Özdoğan, N. Basgelen, and P. Kuniholm (eds.) The Neolithic in Turkey 4. New Excavations \& New Research. Western Turkey. Archaeology and Arts Publications. Istanbul: $139-175$.

Çilingiroğlu Ç. 2016. The Aegean Before and After 7000 BC Dispersal: Defining Patterning and Variability. Neo- $\mathrm{L}$ thics 2016(1): 32-41.

Çilingiroğlu C.., Çakırlar C. 2013. Towards Configuring the Neolithisation of Aegean Turkey. Documenta Praehistorica 40: 21-29. https://doi.org/10.4312/dp.40.3 
Çilingiroğlu C.., Dinçer B., Uhri A., Gürbıyık C., Baykara I., and Çakırlar C. 2016. New Paleolithic and Mesolithic Sites in the Eastern Aegean: Karaburun Archaeologial Survey Project. Antiquity 90(353): 1-6. Project Gallery. https://doi.org/10.15184/aqy.2016.168

Douka K., Efstratiou N., Hald M. M., Henriksen P. S., and Karetsou A. 2017. Dating Knossos and the arrival of the earliest Neolithic in the southern Aegean. Antiquity 91(356): 304-321. https://doi.org/10.15184/aqy.2017.29

Duru R. 2012. The Neolithic of the Lakes Region. Hacilar Kuruçay Höyük - Höyücek - Bademağacı Höyük. In M. Özdoğan, N. Başgelen, and P. Kuniholm (eds.), The Neolithic in Turkey 4. New Excavations \& New Research. Western Turkey. Archaeology \& Arts Publications. Istanbul: $1-65$.

Efstratiou N. 2014. The final Palaeolithic hunting camp of Ouriakos on the island of Lemnos. Eurasian Prehistory 11(1-2): 75-96.

Efstratiou N., Biagi P., and Starnini E. 2014. The Epipalaeolithic site of Ouriakos on the island of Lemnos and its place in the Late Pleistocene peopling of the East Mediterranean region. Adalya XVII: 1-23.

Fletcher A., Baird D., Spataro M., and Fairbairn A. 2017. Early Ceramics in Anatolia: Implications for the production and use of the earliest pottery. The evidence from Boncuklu Höyük. Cambridge Archaeological Journal 27(2): 351-369. https://doi.org/10.1017/S0959774316000767

Galanidou N. 2011. Mesolithic Cave Use in Greece and the Mosaic of Human Communities. Journal of Mediterranean Archaeology 24(2): 219-242.

https://doi.org/10.1558/jmea.v24i2.219

Galanidou N., Perlès C. 2003. The Greek Mesolithic: Problems and Perspectives. British School at Athens Studies 10. British School at Athens. London.

Galik A., Horejs B. 2011. Çukuriçi Höyük - Different Aspects of its Earliest Settlement Phase. In R. Krauss (ed.), Beginnings. New Approaches in Researching the Appearing of the Neolithic between Northwestern Anatolia and the Carpathian Basin. Workshop held at Istanbul Department of the German Archaeological Institute, April

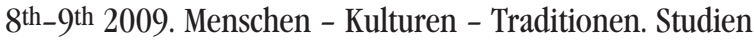
aus den Forschungsclustern des Deutschen Archäologischen Instituts 1. VML Verlag Marie Leidorf. Rahden/Westfalen: 83-94.

Galik, A. in press. Çukuriçi Höyük - Animal exploitation from early Ceramic Neolithic settling to early Bronze Age proto-urban life at the western coast of Anatolia. Documenta Archaeobiologiae 15.
Gatsov I., Özdoğan, M. 1994. Some Epipaleolithic sites from NW Turkey. Ağaçlı, Domalı and Gümüşdere. Anatolica $X X: 97-120$.

Gerritsen F. A., Özbal R., and Thissen L. C. 2013. The earliest Neolithic levels and Barcın Höyük, Northwestern Turkey. Anatolica XXXIX: 53-92.

Gerritsen F. A., Özbal R. 2016. Barcın Höyük and the preFikirtepe Neolithisation of the Eastern Marmara Region. In Ü. Yalçın (ed.), Anatolian Metal VII: Anatolia and neighbours 10.000 years ago. Volume in honour of Mehmet Özdoğan. Blömeke Druck SRS GmbH. Herne: 199208.

de Groot B., Thissen L., Özbal R., and Gerritsen F. 2017. Clay preparation and function of the first ceramics in north-west Anatolia: A case study from Neolithic Barcin Höyük. Journal of Archaeological Sciences: Reports 16: 542-552. https://doi.org/10.1016/j.jasrep.2017.06.028

Guilaine J. 2013. The Neolithic transition in Europe: Some comments on gaps, contacts, arrhythmic model, genetics. In E. Starnini (ed.), Unconformist archaeology. Papers in honour of Paolo Biagi. British Archaeological Reports IS 2528. Archaeopress. Oxford: 55-64.

Guilbeau D., Kayacan N., Altınbilek-Algül Ç., Erdoğu B., and Çevik Ö. 2019. A comparative study of the Initial Neolithic chipped-stone assemblages of Ulucak and Uğurlu. Anatolian Studies 69: 1-20.

https://doi.org/10.1017/S0066154619000024

Hofmanová Z. and 38 co-authors. 2016. Early Farmers from across Europe directly descended from Neolithic Aegeans. Proceedings of the National Academy of Sciences of the United States of America 113: 6886-6891. https://doi.org/10.1101/032763

Horejs B. 2012. Çukuriçi Höyük. A Neolithic and Bronze Age Settlement in the Region of Ephesos. In M. Özdoğan, N. Başgelen, and P. Kuniholm (eds.), The Neolithic in Turkey 4. New Excavations \& New Research. Western Turkey. Archaeology and Arts Publications. Istanbul: 117131.

2016. Aspects of Connectivity on the Centre of the Anatolian Aegean Coast in $7^{\text {th }}$ Millennium BC. In B. P. C. Molloy (ed.), Of Odysseus and Oddities. Sheffield Studies in Aegean Archaeology. Oxbow Books. Oxford: 143167.

2017. Cukuriçi Höyük 1. Anatolia and the Aegean from the $7^{\text {th }}$ to the $3^{\text {rd }}$ Millennium BC. Oriental and European Archaeology 5. Austrian Academy Science Press. Vienna. 
Horejs B., Milić B., Ostmann F., Thanheiser U., Weninger B., and Galik A. 2015. The Aegean in the Early 7 th Millennium BC: Maritime Networks and Colonization. Journal of World Prehistory 28(4): 289-330.

https://doi.org/10.1007/s10963-015-9090-8

Horejs B. in press. Migrating and Creating Social Memories. About the Arrival and Adaptation of the Neolithic in Aegean Anatolia. In Brami M., Horejs B. (eds.), The Central/Western Anatolian Farming Frontier. Proceedings of the Neolithic Workshop held at 10th ICAANE in Vienna, April 2016. Oriental and European Archaeology 13. Austrian Academy Science Press. Vienna: 157-178.

Kaczanowska M., Kozłowski J. K. 2008. Chipped Stone Artefacts. In A. Sampson (ed.), The Cave of the Cyclops: Mesolithic and Neolithic Networks in the Northern Aegean, Greece I. Intra-Site Analysis, Local Industries, and Regional Site Distribution. Prehistory Monographs 21. INSTAP Academic Press. Philadelphia: 169-178.

2014. The Aegean Mesolithic: Material Culture, Chronology, Networks of Contacts. Eurasian Prehistory 11 (1-2): 31-62.

Katsanis M., Tsipidis S., Kotsakis K., and Kousoulakou A. 2008. A 3D digital workflow for archaeological intra-site research using GIS. Journal of Archaeological Science 35: 655-667. https://doi.org/10.1016/j.jas.2007.06.002

Kotsakis K. 2003. From the Neolithic side: the Mesolithic/ Neolithic interface in Greece. In: N. Galanidou, C. Perlès (eds.), The Greek Mesolithic. Problems and Perspectives. British School at Athens Studies 10. British School at Athens. London: 217-221.

2008. A Sea of Agency: Crete in the Context of the Earliest Neolithic in Greece. In V. Isaakidou, P. Tomkins (eds.), Escaping the Labyrinth: The Cretan Neolithic in Context. Oxbow Books. Oxford: 52-75.

2014. Domesticating the periphery. New Research into the Neolithic of Greece. Pharos 20(1): 41-73.

Kozłowski J. K. 2016. The Mesolithic of the Aegean Basin: Cultural Variability, Subsistence Economy, Interregional Links and Seafaring. In R. Krauss and H. Floss (eds.), Southeast Europe before Neolithisation. Proceedings of the International Workshop within the Collaborative Research Centres SFB 1070 "RessourcenKulturen", Schloss Hohentübingen, 9th of May 2014. RessourcenKulturen 1. Pro Business Digital Printing Deutschland GmbH. Tübingen: 41-64.

Lazaridis I. and 51 co-authors. 2016. Genomic insights into the origin of farming in the ancient Near East. Nature 536: 419-424. https://doi.org/10.1038/nature19310
Lichter C. 2005. Western Anatolia in the Late Neolithic and Early Chalcolithic: the actual state of research. In C. Lichter (ed.), How did farming reach Europe? Anatolian-European relations from the second half of the $7^{\text {th }}$ through the first half of the $6^{\text {th }}$ millennium cal BC. BYZAS 2. Ege Yayinlari. Istanbul: 59-74.

Mathieson I. and 116 co-authors. 2018. The Genomic History Of Southeastern Europe. Nature 555: 197-203. https://doi.org/10.1038/nature25778

Maniatis Y. 2014. Radiocarbon dating of the major cultural phases in prehistoric Macedonia: Recent developments. In E. Stefani, N. Merousis, and A. Dimoula (eds.), Proceedings of the international conference on "100 years research in prehistoric Macedonia 1912-2012", Archaeological Museum of Thessaloniki. Archaeological Museum of Thessaloniki. Thessaloniki: 205-222.

Mellaart J. 1958. Excavations at Hacilar: First Preliminary Report. Anatolian Studies 8: 127-156.

https://doi.org/10.2307/3642417

1970. Excavations at Hacılar. Edinburgh University Press. Edinburgh.

Milić B. 2018. Lithics and Neolithisation - Cukuriçi Höyük in Anatolia and the Aegean. Unpublished PhD thesis. University of Tübingen. Tübingen.

Milić B., Horejs B. 2017. The Onset of Pressure Blade Making in Western Anatolia in the 7th Millennium BC: A Case Study from Neolithic Çukuriçi Höyük. In B. Horejs (ed,), Cukuriçi Höyük 1. Anatolia and the Aegean from the $7^{\text {th }}$ to the $3^{\text {rd }}$ Millennium BC. Oriental and European Archaeology 5. Austrian Academy of Sciences Press. Vienna: $27-52$.

Milojčić V. 1950. Zur Chronologie der jüngeren Steinzeit Griechenlands. Jahrbuch des Deutschen Archäologischen Instituts 65-66: 1-90.

Munro N. D., Stiner M. C. 2015. Zooarchaeological Evidence for Early Neolithic Colonization at Franchthi Cave (Peloponessos, Greece). Current Anthropology 56(4): 596-603.

https://www.journals.uchicago.edu/doi/10.1086/682326

Özbek 0., Erdoğu B. 2014. Initial occupation of the Gelibolu Peninsula and the Gökçeada (Imbroz) island in the pre-Neolithic and Early Neolithic. Eurasian Prehistory 11 (1-2): 97-128.

Özdoğan M. 2008. An alternative approach in tracing changes in demographic composition. In J.-P. Bocquet-Appel and 0 . Bar-Yosef (eds.), The Neolithic demographic transition and its consequences. Springer. Dordrecht: 139-178. 
2010. Westward Expansion of the Neolithic Way of Life: Sorting the Neolithic Package into Distinct Packages. In P. Matthiae, F. Pinnock, L. Nigro, and N. Marchett (eds.), Proceedings of the $6^{\text {th }}$ International Congress on the Archaeology of the Ancient Near East May, 5th-10th 2008, Sapienza Università di Roma. Harrassowitz Verlag. Wiesbaden: 883-897.

2011. Archaeological Evidence on the Westward Expansion of Farming Communities from Eastern Anatolia to the Aegean and the Balkans. Current Anthropology 52 (4): 415-430. https://doi.org/10.1086/658895

2014. The quest for new criteria in defining the emergence and the dispersal of Neolithic way of life. In C. Manen, T. Perrin, and J. Guilaine (eds.), La transition néolithique en Méditerranée. Actes du colloque Transitions en Méditerranée, ou comment des chasseurs devinrent agriculteurs, Toulouse. Éditions Errance. Arles: 77-89.

Özdoğan M., Başgelen N. 1999. Neolithic in Turkey. The Cradle of Civilization. New Discoveries. Arkeoloji ve Sanat Yayınları. Istanbul.

Özdoğan M., Başgelen N., and Kuniholm P. 2012. The Neolithic in Turkey. New Excavations \& New Research. Volume 4. Western Turkey, Istanbul.

Perlès C., Vaughan P. C., Renfrew C., and Aspinall A. 1990. Les industries lithiques taillees de Franchthi (Argolide, Grece) 2, Fascicle 5. Les industries du Mesolithique et du Neolithique Initial. Indiana University Press. Bloomington and Indianapolis.

Perlès C. 2001. The Early Neolithic in Greece. Cambridge University Press. Cambridge.

2003a. An alternate (and old-fashioned) view of Neolithisation in Greece. Documenta Praehistorica 30: 99113. https://doi.org/10.4312/dp.30.5

2003b. The Mesolithic at Franchthi: An Overview of the Data and Problems. In N. Galanidou and C. Perlès (eds.), The Greek Mesolithic: Problems and Perspectives. British School at Athens Studies 10. British School at Athens. London: 79-87.

2005. From the Near East to Greece: Let's reverse the focus. Cultural elements that didn't transfer. In C. Lichter (ed.), How did farming reach Europe? AnatolianEuropean relations from the second half of the $7^{\text {th }}$ through the first half of the $\sigma^{\text {th }}$ millennium cal $B C$. BYZAS 2. Ege Yayınları. Istanbul: 275-290.

2019. Special Issue: Personal Ornaments in Early Prehistory - Cultural Implications of Uniformity in Ornament Assemblages: Palaeolithic and Mesolithic Orna- ments From Franchthi Cave, Greece. PaleoAnthropo$\log y$ 2019: 196-207. http://www.paleoanthro.org/me dia/journal/content/PA20190196.pdf

Perlès C., Quiles A., and Valladas H. 2013. Early seventhmillennium AMS dates from domestic seeds in the Initial Neolithic at Franchthi Cave (Argolid, Greece). Antiquity 87: 1001-1015. https://doi.org/10.1017/S0003598X00049826

Pilaar Birch S. E., Atıcı L., and Erdoğu B. 2019. Spread of domestic animals across Neolithic western Anatolia: New stable isotope evidence from Uğurlu Höyük, the island of Gökçeada, Turkey. PLoS ONE 14(10): e0222319. https:// journals.plos.org/plosone/article?id=10.1371/journal.po ne. 0222319

Reingruber A. 2011. Early Neolithic settlement patterns and exchange networks in the Aegean. Documenta Praehistorica 38: 291-305. https://doi.org/10.4312/dp.38.23

2015. Preceramic, Aceramic or Early Ceramic? The Radiocarbon Dated Beginning of the Neolithic in the Aegean. Documenta Praehistorica 42: 147-158. https://doi.org/10.4312/dp.42.9

2017. Foragers, Fishers and Farmers in the Aegean (12,000-6000 cal BC). In M. Mărgărit and A. Boroneanţ (eds.), From hunter-gatherers to farmers: Human adaptations at the end of the Pleistocene and the first part of the Holocene. Papers in Honour of Clive Bonsall. Cetatea de Scaun. Târgovişte: 203-215.

Rose M. 1995. Fishing at Franchthi Cave, Greece: Changing environments and patterns of exploitation. Old World Archaeology Newsletter 18: 21-26.

Sampson A. 2010. Mesolithic Greece: 9000-6500 BC. Palaeoenvironment, Palaeoeconomy, Technology. Ion. Athens.

2014. The Aegean Mesolithic: environment, economy and seafaring. Eurasian Prehistory 11(1-2): 63-74.

Sampson A., Kaczanowska M., and Kozłowski J. K. 2010. The prehistory of the island of Kythnos and the Mesolithic settlement at Maroulas. Polish Academy of Arts and Sciences - University of the Aegean. Krakow.

Schmidt K. 2006. Sie bauten die ersten Tempel. Das rätselhafte Heiligtum der Steinzeitjäger. Die archäologische Entdeckung am Göbekli Tepe. C. H. Beck. München.

Schwall Ch., Brandl M., Gluhak T. M., Milić B., Betina L., Sørensen L., Wolf D., and Horejs B. in press. From near and far. Stone procurement and exchange at Çukuriçi Höyük in Western Anatolia. Journal of Lithic Studies (in press). 
Séfériadès M. 2007. Complexity of the processes of Neolithisation: Tradition and modernity of the Aegean world at the dawn of the Holocene period (11-9 kyr). Quaternary International 167-168: 177-185.

https://doi.org/10.1016/j.quaint.2006.11.008

Shennan S. J., Downey S. S., Timpson A., Edinborough K., Colledge S., Kerig T., Manning K., and Thomas M. G. 2013. Regional Population Collapse Followed Initial Agriculture Booms in Mid-Holocene Europe. Nature Communications 4: 1-8. https://doi.org/10.1038/ncomms3486

Simmons A. 2014. Stone Age Sailors: Paleolithic Seafaring in the Mediterranean. Left Coast Press. Walnut Creek, CA.

Souvatzi S. G. 2008. A Social Archaeology of Households in Neolithic Greece. An Anthropological Approach. Cambridge University Press. Cambridge.

Sørensen L., Pétrequin P., Pétrequin A.-M., Errera M., Horejs B., and Herbaut F. 2017. Les limites sud-orientales des jades alpins (Grèce et Turquie)/The south-eastern limits of Alpine jades (Greece and Turkey). In P. Petrequin, E. Gauthier, and A.-M. Petrequin (eds.),Jade. Objets-signes et interprétations sociales des jades alpins dans l'Europe néolithique 3. Imprimerie Messages. Toulouse: 491520.

Stiner M. C., Munro N. D. 2011. On the evolution of diet and landscape during the Upper Paleolithic through Mesolithic at Franchthi Cave (Peloponnese, Greece). Journal of Human Evolution 60: 618-636.

https://doi.org/10.1016/j.jhevol.2010.12.005

Strasser T., Panagopoulou E., Runnels C., Murray P., Thompson N., Karkanas P., McCoy F., and Wegmann K. 2010. Stone Age seafaring in the Mediterranean: Evidence from the Plakias region for Lower Palaeolithic and Mesolithic habitation of Crete. Hesperia 79: 145-190.

http://dx.doi.org/10.2972/ hesp.79.2.145

Takaoğlu T., Korkut T., Erdoğu B., and Işın G. 2014. Archaeological Evidence for $9^{\text {th }}$ and $8^{\text {th }}$ millennia BC at Girmeler Cave near Tlos in SW Turkey. Documenta Praehistorica 41: 111-118. https://doi.org/10.4312/dp.41.6

Theocharis D. R. 1973. Neolithic Greece. National Bank of Greece. Athens.

Trantalidou K. 2003. Faunal remains from the earliest strata of the Cave of Cyclope, Youra. In N. Galanidou, C. Perlès (eds.), The Greek Mesolithic: Problems and perspec- tives. British School at Athens Studies 10. British School at Athens. London: 143-172.

2010. Dietary adaptations of coastal people in the Aegean archipelago during the Mesolithic period: The macrofauna assemblages of Maroulas on Kythnos. In A Sampson, M. Kaczanowska, and J. K. Kozłowski (eds.), The prehistory of the island of Kythnos and the Mesolithic settlement at Maroulas. Polish Academy of Arts and Sciences - University of the Aegean. Krakow: 163177.

2011. From Mesolithic fisherman and bird hunters to Neolithic goat herders: The transformation of an island economy in the Aegean. In A. Sampson (ed.), The Cave of the Cyclops. The Mesolithic and Neolithic networks in the Northern Aegean, Greece II. Bone Tool Industries, Dietary Resources and the Paleoenvironment, and Archeometrical Studies. INSTAP Academic Press. Philadelphia: 53-101.

Vigne J.-D. and 12 co-authors. 2012. First wave of cultivators spread to Cyprus at least 10,600 yrs ago. Proceedings of National Academy of Sciences of the United States of America 109(22): 8445-8449.

https://doi.org/10.1073/pnas.1201693109

Vigne J.-D., Zazzo A., Cucchi T., Carrère I., Briois F., and Guilaine J. 2014. The transportation of mammals to Cyprus sheds light on early voyaging and boats in the Mediterranean Sea. Eurasian Prehistory 10(1-2): 157-176.

Watkins T. 2005. The Neolithic revolution and the emergence of humanity: a cognitive approach to the first comprehensive world-view. In J. Clarke (ed.), Archaeological Perspectives on the Transmission and Transformation of Culture in the Eastern Mediterranean. Levant Supplementary Series 2. Council for British Research in the Levant \& 0xbow Books. 0xford: 84-88.

2010. New light on Neolithic revolution in south-west Asia. Antiquity 84: 621-634.

https://doi.org/10.1017/S0003598X00100122

2018. The Epipaleolithic-Neolithic as the pivotal transformation of human history. Documenta Praehistorica 45: 14-29. https://doi.org/10.4312/dp.45.2

Weninger B., Clare L., Gerritsen F., Horejs B., Krauß R., Linstädter J., Özbal R., and Rohling E. J. 2014. Neolithisation of the Aegean and Southeast Europe during the 66006000 cal BC period of Rapid Climate Change. Documenta Praehistorica 41: 1-31. https://doi.org/10.4312/dp.41.1

\section{back to contents}

